\title{
Polymerase chain reaction fails to incriminate exogenous retroviruses HTLV-I and HIV-1 in rheumatological diseases although a minority of sera cross react with retroviral antigens
}

Paul N Nelson, Andrew M L Lever, Felix E Bruckner, David A Isenberg, Nicos Kessaris, Frank C Hay

\begin{abstract}
Objectives-To investigate the presence of antibodies to HTLV and HIV retroviral antigens in the rheumatological diseases rheumatoid arthritis (RA), polymyositis/ dermatomyositis (PM/DM), primary Sjögren's syndrome (pSS), and systemic lupus erythematosus (SLE), and to use polymerase chain reaction (PCR) to seek these exogenous retroviruses in proviral form in cellular DNA from these patients. Methods-Thirty patients with active RA, 13 with PM, 14 with pSS and five with SLE were recruited and their sera tested for antibodies to HTLV-I in enzyme linked immunosorbent assay (ELISA) and Western blot analysis. Seropositivity to HIV-1 was also sought. DNA was extracted from peripheral blood lymphocytes, synovial tissue and muscle biopsies and tested by polymerase chain reaction using consensus primers for HTLV-I and HIV-1. Results-In HTLV-I ELISA, nine rheumatological sera (4/30 RA, 3/13 PM/DM and 2/5 SLE patients) were considered positive; 14 from pSS patients and 30 from normal subjects were negative. In a control group which included osteoarthritis, Crohn's disease and bacterial endocarditis patients, only two of 80 proved positive in this system. Validation of these sera by Western blotting generally revealed weak reactivity against a variety of HTLV-I antigens. PCR of genomic DNA derived from patients' peripheral blood mononuclear cells did not reveal the presence of HTLV-I and HIV-1 target sequences.
\end{abstract}

Conclusions-This study shows that PCR precludes HTLV-I and HIV-1 infection as causative agents in these rheumatological diseases although a minority of patients possess antibodies that are weakly crossreactive with retroviral antigens.

(Ann Rheum Dis 1994; 53: 749-754)

The aetiology of rheumatological diseases such as rheumatoid arthritis (RA), polymyositis (PM), primary Sjögren's syndrome (pSS) and systemic lupus erythematosus (SLE) has yet to be established, but appears to be multifactorial, perhaps resulting from complex interactions between genetic, hormonal and environmental factors. ${ }^{1}$ Retroviruses have been implicated as causative agents in these diseases. ${ }^{2}$ Of particular interest in humans are the oncoviridae (which induce tumour formation), for example human $\mathrm{T}$ cell lymphotrophic virus (HTLV-I), which has been associated with a chronic inflammatory arthropathy, ${ }^{3}$ and the lentiviridae (slow viruses), for example human immunodeficiency virus (HIV-1). Furthermore, patients infected with HTLV-I or HIV-1 may develop rheumatological manifestations. ${ }^{45}$ Lentiviruses such as caprine arthritis encaphalitis virus and maedi-visna virus have been associated with rheumatological disorders of goats and sheep, respectively. ${ }^{6}$

Serological studies in patients with pSS, SLE and juvenile chronic RA have revealed cross reactive antibodies to $\mathrm{HIV}-1$ gag $\mathrm{p} 24,{ }^{7}$ and antibodies to HTLV-I have been detected in patients with $\mathrm{pSS}^{8}$ Retroviral antigens have also been detected at the site of disease: $45 \%$ of RA synovial sections appear positive using antibodies to HTLV-I p24 and p19 ${ }^{9}$ and a retrovirus-like particle has been detected in a human $\mathrm{T}$ cell line co-cultured with salivary gland tissue from one primary Sjögren's patient. ${ }^{10}$ However, a number of other studies have failed to detect antibodies to retroviral antigens in rheumatological diseases. ${ }^{11} 12$

There is thus ambiguity in the serological evidence incriminating retrorviruses and hence a need to clarify the role of putative retroviral agents in the pathogenesis of rheumatological diseases. To date there have been few reports on the detection of retroviral agents in these diseases using direct molecular biology approaches such as the polymerase chain reaction (PCR) ${ }^{13}$ Consequently, we sought to assess the presence of antibodies to retroviral antigens in a number of rheumatological diseases and used PCR to attempt to identify or exclude candidate agents.

\section{Patients and methods}

SUBJECTS

Sera were obtained from 62 patients attending rheumatology clinics at St George's Hospital, and the Middlesex Hospital, London. Table 1 gives details of patient groups. Thirty patients had RA as defined by the revised criteria of the American College of Rheumatology (ACR). ${ }^{14}$ Of 13 patients diagnosed using the criteria of Bohan et $a l,,^{15}$ eight had adult PM and five 
Table 1 Patient group details

\begin{tabular}{|c|c|c|c|c|c|c|}
\hline & $R A$ & $P M / D M$ & $p S S$ & $S L E$ & $N$ & $C G$ \\
\hline Number & 30 & 13 & 14 & 5 & 30 & 80 \\
\hline Mean (SD) & $59(14 \cdot 2)$ & $46 \cdot 7(19 \cdot 6)$ & $62(13 \cdot 4)$ & $35 \cdot 2(10 \cdot 1)$ & $29.9(10 \cdot 2)$ & $55.4(21.9)$ \\
\hline Range & $30-82$ & $25-70$ & $45-88$ & $24-50$ & $20-62$ & 3-91 \\
\hline Ethnic origin & $30 \mathrm{~W}$ & $8 \mathrm{~W}, 5 \mathrm{WI}$ & $13 \mathrm{~W}, 1 \mathrm{~W} 1$ & $4 \mathrm{~W}, 1 \mathrm{~W} 1$ & $21 \mathrm{~W}, 9 \mathrm{Or}$ & 75W,5WI \\
\hline
\end{tabular}

$\mathrm{RA}=$ Rheumatoid arthritis; $\mathrm{PM} / \mathrm{DM}=$ polymyositis/dermatomyositis; pSS = primary Sjögren's syndrome; SLE = systemic lupus erythematosus; $\mathrm{N}=$ normal subjects; $\mathrm{CG}=$ control group (patients with osteoarthritis, Crohn's disease and bacterial endocarditis). W = White; WI = West Indian; Or = Oriental. visualised using ethidium bromide $0.5 \mu \mathrm{g} / \mathrm{ml}$. The presence of exogenous retroviruses was assessed using sense and antisense primers: SK43 (Cetus, 5'-CGGATACCCAGTCTACGTGT-3') and SK44 (Cetus, 5'-GAGCCGATAACGCGTCCATCG-3') for HTLV-I tax, and SK100 (5'-ATCAAGCAGCCATGCAAAT-3') and SK104 (5'-CCTTTGGTCCTTGTCTTATGTC-3') for HIV-1 gag region (conditions: $95^{\circ}$ for one minute, $55^{\circ}$ for one minute, $72^{\circ}$ for two minutes, 35 cycles, $2.5 \mathrm{mmol} / 1 \mathrm{MgCl}_{2}$ ). DNA from human T cell lines known to be infected with HTLV-I (MT2 cells) and HTLV-IIIb infected Jurkat cells were used as positive controls. These provided $159 \mathrm{bp}$ and $291 \mathrm{bp}$ products, respectively, confirmed by Southern blotting using probes SK45 (5'-ACGCCCTACTGGCCACCTGTCCAGAGCATCAGATCACCTG-3', 7447-7486 HTLV-I) and SK19 (5'-ATCCTGGGATTAAATAAAATAGTAAAAGAATGTATAGCCCTAC-3', 1595-1635 HIV-1), respectively, as previously described. ${ }^{18}$ 19 PCR analysis using $\beta$-globin primers of serially diluted genomic DNA preparations from human peripheral blood lymphocytes allowed us to determine a cut off point of one single copy gene per $10^{5}$ cells. (20) and osteoarthritis (30)). Ethics committee approval was obtained for additional venous blood to be collected during the routine clinical management of patients. All samples were coded and tested blind by the scientific investigator.

SEROLOGY-ELISA AND WESTERN BLOTTING Sera were screened in enzyme linked immunosorbent assay (ELISA) for antibodies to HTLV-I viral lysate (derived from Hut-102 B2 T-Lymphocyte cell line: Biotech/DuPont kit, distributed by Ortho Diagnostic Systems Ltd, NEA-510B) and to HIV-1 using a Wellcozyme HIV-1 anti-p24 kit (Murex VK60). Samples were tested twice and cut off values for positivity were selected as directed in specification protocols. Sera considered positive in ELISA were further evaluated in Western blotting (Biotech/DuPont HTLV-I kit, Ortho Diagnostic Systems Ltd, PN8005; Biotech/DuPont HIV-1 kit, Ortho Diagnostic Systems Ltd, PN8003). A particle agglutination test was used for the detection of rheumatoid factor (Serodia-RA, Fujirebio Inc, Japan). Agglutination of sensitised particles (final serum dilution 1:40 or greater) was interpreted as positive.

POLYMERASE CHAIN REACTION

DNA was obtained by phenol/chloroform extraction or hypotonic cell lysis from $10^{7}$ peripheral blood mononuclear cells, muscle biopsies and synovial tissues. Genomic DNA ( $1 \mu \mathrm{g}$, equivalent to $10^{5}$ cells) was validated in PCR using $\beta$-globin primers: PC04 (Cetus N808-0013, 5'-CAACTTCATCCACGTTCACC-3') and GH20 (Cetus N808-0014, 5'-GAAGAGCCAAGGACAGGTAC-3') to yield a $268 \mathrm{bp}$ product (conditions: $95^{\circ}$ for one minute, $55^{\circ}$ for one minute, $72^{\circ}$ for two minutes, 40 cycles, $4 \mathrm{mmol} / 1 \mathrm{MgCl}_{2}$ ) in a $2.5 \%$ agarose gel
STATISTICAL EVALUATION

Statistical analysis was carried out using Fisher's exact test.

\section{Results}

SEROLOGICAL EVALUATION OF RHEUMATOLOGICAL PATIENTS

Enzyme linked immunosorbent assay-In the HTLV-I ELISA, four of 30 RA sera were considered positive, giving optical density values greater than the cut off value (figure); three were from male patients and one from a female. Of 13 PM/DM patients, three were positive: two white (male and female) and one West Indian (female). In our study all $14 \mathrm{pSS}$ sera were negative and two of five SLE sera were considered positive; both were white. Within groups, there was no difference in mean age and disease duration for those considered positive in this assay system. Thirty normal sera were also negative in the HTLV-I ELISA; in the disease control group, two of 80 patients were considered positive: one 73 year old male bacterial endocarditis patient and one 79 year old male patient with osteoarthritis, both white. Overall the data showed no significant association of HTLV-I ELISA reactivity in rheumatoid arthritis patients in relation to the disease control group (table 2). Levels of significance were only achieved for HTLV-I in PM/DM patients and SLE patients, in relation to inflammatory diseases (Crohn's and bacterial endocarditis) or patients with osteoarthritis. There was no association of retroviral antibodies and rheumatoid factor. Sera were also tested against recombinant HIV-1 p24. However, in this assay system only one RA serum and one pSS serum (derived from white subjects), and two control group sera (derived 


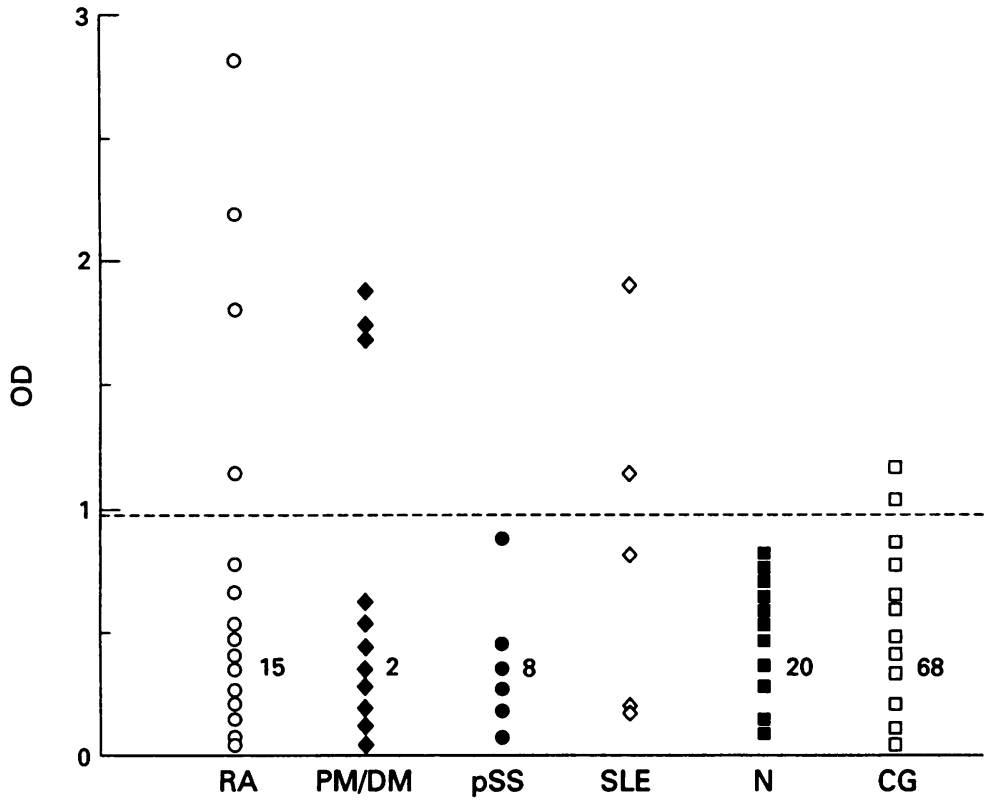

Evaluation of sera for the presence of antibodies to HTLV-I. Samples (duplicates) from patients with rheumatoid arthritis $(R A)$, polymyositis/dermatomyositis (PM/DM), primary Sjögren's syndrome ( $P S S)$, and systemic lupus erythematosus (SLE), and normal (N), and control group (CG) subjects were screened in ELISA using an HTLV-I viral lysate (derived from Hut-102 B2 T lymphocyte cell line). Broken line indicates cut off: $\geqslant 0.95$ positive for HTLV-I. Number adjacent to symbol indicates additional sera with equivalent optical density value.

from two white osteoarthritis patients) were positive.

Western blotting-None of the sera showing reactivity by ELISA was positive for HTLV-I compared with control. However, these sera demonstrated weak reactivity against a range of retroviral antigens (table 3), in particular, p21 (recombinant transmembrane envelope protein), p24 (major gag capsid protein), p38 (transactivator protein) and gp46 (outer envelope glycoprotein). Only one RA patient showed strong binding to p19 (major gag matrix protein); three RA, two PM/DM, two SLE, two normal sera and two disease control group sera demonstrated weak reactivity against p24 'tax' (transactivator protein). Evaluation of 13 additional sera (eight rheumatoid, five normal) that were negative by ELISA, revealed weak reactivity to p42 tax only and not to other retroviral antigens, by Western blotting. Of the four sera considered positive for HIV-1 by ELISA, only one (S120) demonstrated reactivity for p24 by HIV-1 Western blot. Further analysis of sera using

Table 2. Prevalance of antibodies to HTLV-I and HIV-1 in rheumatological diseases as determined by ELISA

\begin{tabular}{|c|c|c|c|c|c|}
\hline & \multicolumn{2}{|c|}{ HTLV-I ELISA } & \multirow{2}{*}{$\begin{array}{l}\text { Fisher's exact test } \\
C G\end{array}$} & \multicolumn{2}{|c|}{ HIV-1 ELISA } \\
\hline & $+v e$ & $-v e$ & & $+v e$ & $-v e$ \\
\hline $\begin{array}{c}\mathrm{RA}(\mathrm{n}=30) \\
\mathrm{rf}+/-\mathrm{ve}\end{array}$ & $\begin{array}{l}4 \\
3 / 1\end{array}$ & $\begin{array}{l}26 \\
18 / 8\end{array}$ & 0.074 & 1 & 29 \\
\hline $\begin{array}{l}\mathrm{PM} / \mathrm{DM}(\mathrm{n}=13) \\
\mathrm{rf}+/-\mathrm{ve}\end{array}$ & $\begin{array}{l}3 \\
2 / 1\end{array}$ & $\begin{array}{c}10 \\
3 / 7\end{array}$ & $0.017^{\star}$ & 0 & 13 \\
\hline $\begin{array}{l}\operatorname{SLE}(n=5) \\
\text { rf }+/-v e\end{array}$ & 2 & $\begin{array}{l}3 \\
0 / 3\end{array}$ & $0.015^{\star}$ & 0 & 5 \\
\hline $\mathrm{pSS}(\mathrm{n}=14)$ & 0 & 14 & 0.723 & 1 & 13 \\
\hline $\begin{array}{l}N(n=30) \\
C G N=80)\end{array}$ & 0 & $\begin{array}{l}30 \\
78\end{array}$ & & 0 & $\begin{array}{l}30 \\
78\end{array}$ \\
\hline
\end{tabular}

rf = Rheumatoid factor. Fisher's exact test for association of retroviral antibodies and rheumatoid factor based on combined RA, PM/DM and SLE data was $p=0 \cdot 26$. Statistical analysis of rheumatoid groups in comparison with $\mathrm{OA}$ and inflammatory diseases (Crohn's disease and bacterial endocarditis) were: RA $0.150,0.057$; PM 0.069, 0.024*; SLE $0.045^{\star}, 0.019^{\star}$; pSS $0.681,0.781$. ${ }^{\star}$ Significant association $(p<0 \cdot 05)$. complementary blots revealed RA serum (S33) and SLE serum (S94) showing medium band intensities for HIV-1 p24.

POLYMERASE CHAIN REACTION: DETECTION OF HTLV-I AND HIV-1

To assess if the nine rheumatoid samples considered positive by HTLV-I ELISA possessed intregrated provirus, DNA was initially extracted from peripheral blood lymphocytes. Using $\beta$-globin primers we were able to amplify a $240 \mathrm{bp}$ product in PCR from all samples, thereby validating genomic DNA. However, PCR using HTLV-I tax primers failed to amplify an expected $159 \mathrm{bp}$ product. This target sequence was amplified from DNA extracted from HTLV-I infected MT2 cells. A further $13 \mathrm{RA}, 10 \mathrm{PM} / \mathrm{DM}$, and two SLE samples also proved negative for HTLV-I by PCR. Samples were also tested using HIV-1 gag sense and antisense primers. Although a $291 \mathrm{bp}$ product was amplified from HIV-1 infected Jurkat cells, this target sequence was not amplified from patient samples. In order to establish if retrovirus might be at the site of inflammation, mononulear cells from four RA synovial effusions and two PM muscle biopsies were obtained. However, despite DNA being extracted and validated using $\beta$-globin primers, all samples proved negative for HTLV-I and HIV-1.

\section{Discussion}

This study attempted to correlate serological findings of reactivity to retroviruses with PCR. Our data show that nine of 62 rheumatological sera were considered positive by HTLV-I ELISA, giving optical density values greater than the cut off point. A previous study seeking antibodies to HTLV-I, -II and III in 60 RA patients failed to incriminate these retroviruses. ${ }^{12}$ In a Japanese study of 54 patients with PM/DM, only one with PM/SLE showed a slightly increased titre of antibody to HTLV-I in comparison with age-, sex- and racematched individuals. ${ }^{20}$ Other studies in Sweden and the USA also found no evidence to associate HTLV-I with PM/DM. ${ }^{21}{ }^{22}$ The prevalence of positive sera in the HTLV-I ELISA may be attributed to the assay system used, together with differences in cohort numbers and ethnic group. Statistical analysis revealed significance only when PM/DM was compared with an inflammatory disease group (Crohn's and bacterial endocarditis), and when SLE was compared with the inflammatory disease group and osteoarthritis; however, the significance achieved was probably attributable to the small sample sizes. In the PM/DM group, one patient found positive was West Indian. A previous study ${ }^{23}$ examining the HTLV-I status in 80 patients (46 with SLE, eight SLE/pSS and 38 with PM/DM) found that only one serum was positive-that from a female SLE patient of West Indian origin; HTLV-I is endemic in the West Indies. Hence the ethnic origin is an important factor when considering serological evidence. Our study 
Table 3 Western blot analysis of sera positive for HTLV-I/HIV-1 by ELISA

\begin{tabular}{|c|c|c|c|c|c|c|c|c|c|c|c|c|c|c|c|c|c|}
\hline \multirow[t]{3}{*}{ Sample } & \multicolumn{17}{|c|}{ Western Blot } \\
\hline & \multicolumn{9}{|c|}{$H T L V-I$} & \multicolumn{8}{|l|}{$H I V-1$} \\
\hline & $p 21$ & $p 19$ & $p 24$ & $p 26$ & $p 32$ & $p 38$ & $p 42$ & $g p 46$ & p53 & $g p 160$ & $g p 120$ & $p 66$ & $p 55$ & $p 51$ & $g p 41$ & $p 24$ & $p 17$ \\
\hline \multicolumn{18}{|l|}{ RA } \\
\hline S25* & + & - & - & - & - & - & + & - & - & - & - & - & + & - & - & - & - \\
\hline S33* & - & - & - & - & - & - & + & - & - & - & - & - & - & - & - & ++ & + \\
\hline S57* & - & +++ & - & - & - & - & - & - & - & - & - & - & - & - & - & - & - \\
\hline S62^ & - & - & - & - & - & + & + & + & - & - & - & - & - & - & - & + & - \\
\hline S80 & - & - & - & - & - & - & + & - & - & - & - & - & - & - & - & - & - \\
\hline \multicolumn{18}{|l|}{$\mathrm{PM} / \mathrm{DM}$} \\
\hline $\mathrm{S} 27^{\star}$ & + & - & - & - & - & + & - & - & - & - & - & - & - & + & - & + & + \\
\hline S28* & + & - & - & - & - & - & ++ & - & - & - & - & - & - & - & - & + & + \\
\hline $\mathrm{S} 29^{\star}$ & - & + & - & - & - & + & + & - & - & - & - & - & - & - & - & + & - \\
\hline \multicolumn{18}{|l|}{ SLE } \\
\hline S93* & - & - & + & - & - & - & + & + & - & - & - & - & - & - & - & - & - \\
\hline S94* & - & - & - & - & - & - & + & - & - & - & - & - & - & - & - & ++ & + \\
\hline \\
\hline S105 & - & - & - & - & - & - & - & - & - & - & - & - & - & - & - & + & - \\
\hline \multicolumn{18}{|l|}{ Normal } \\
\hline $\mathrm{S} 42$ & - & - & - & - & - & - & + & - & - & - & - & - & - & - & - & - & - \\
\hline \multicolumn{18}{|l|}{ CG OA } \\
\hline $\begin{array}{l}S 138^{x} \\
\text { S118 }\end{array}$ & - & $\stackrel{+}{-}$ & $\begin{array}{l}+ \\
-\end{array}$ & $\begin{array}{l}- \\
-\end{array}$ & - & - & $\begin{array}{l}+ \\
-\end{array}$ & $\overline{-}$ & $\begin{array}{l}- \\
-\end{array}$ & $\overline{-}$ & $\begin{array}{l}- \\
-\end{array}$ & - & - & - & - & + & - \\
\hline S120 & - & - & - & - & - & - & + & - & - & - & - & - & - & - & $\begin{array}{l}- \\
-\end{array}$ & ++ & - \\
\hline \multicolumn{18}{|l|}{ CG BE } \\
\hline $\mathrm{S} 207^{\star}$ & - & - & + & - & - & - & + & - & - & - & - & - & - & - & - & - & - \\
\hline $\begin{array}{l}\text { +ve Contr. } \\
\text { HTLV } \\
\text { HIV }\end{array}$ & $\begin{array}{l}+++ \\
-\end{array}$ & $\begin{array}{l}+++ \\
-\end{array}$ & $\begin{array}{l}+++ \\
-\end{array}$ & $\begin{array}{l}++ \\
-\end{array}$ & $\begin{array}{l}+++ \\
-\end{array}$ & $\begin{array}{l}+++ \\
-\end{array}$ & $\begin{array}{l}++ \\
-\end{array}$ & $\begin{array}{l}+++ \\
-\end{array}$ & $\begin{array}{l}+++ \\
-\end{array}$ & $\overline{+++}$ & $\overline{+}++$ & $\overline{++}$ & $\overline{++}$ & $\overline{+++}$ & $\overline{++}$ & $\overline{+}++$ & - \\
\hline
\end{tabular}

$\mathrm{RA}=$ Rheumatoid arthritis; $\mathrm{PM} / \mathrm{DM}=$ polymyositis/dermatomyositis; $\mathrm{SLE}=$ systemic lupus erythematosus; $\mathrm{pSS}=$ primary Sjögren's syndrome; CG OA, CG BE = control group osteoarthritis and bacterial endocarditis; +veContr. = positive control (sera derived from HTLV-I and HIV-1 infected individuals. Band intensity: +++high; ++medium; +weak; -no staining. ${ }^{\star}$ Sera positive for HTLV-I in ELISA. sera positive for HIV-1 p24 in ELISA. HTLV-I: p21, recombinant transmembrane envelope protein p53, precursor of gag proteins; p32, p38, p26, gag protein intermediates; gp46 outer envelope glycoprotein, p42; transactivato protein, p24; major gag capsid protein p 19, major gag matrix protein. HIV-1: gp 160, precursor of envelope glycoprotein; proter envelope glycoprotein; $\mathrm{p} 66$, 51 reverse glycoprotein; p31 endonuclease component of polymerase region; p55 precursor of gag proteins; p24, p17, gag proteins.

revealed that none of the pSS sera was positive for HTLV-I and only one was positive for HIV1 p24 in ELISA. In an HTLV-I endemic area of Japan (prevalence of serum antibodies in adults over 40 years, $10-25 \%), 36 \%$ of pSS patients were positive for HTLV-I although clinical comparisons between HTLV-positive/ negative pSS patients showed no significant difference. ${ }^{8}$ In contrast, a study in a nonHTLV-I-endemic area showed no reactivity with either HTLV-I structural proteins or envelope proteins of $\mathrm{HIV}-1$, but did find antibodies to HIV-1 p24 in $14(30 \%)$ of 47 patients with pSS. ${ }^{24}$

It was possible that optical density values above the cut off in HTLV-I ELISA may have been attributable to reactivity with nonHTLV-I antigens in the lysate. Thus validation of results was required in Western blotting. Evidently none of the sera in our study was HTLV-I positive according to accepted criteria (reactivity with antigens p21, p19, p24, p28, $\mathrm{p} 38$, gp 46). A study using Western blotting has shown that in SLE, $36 \%$ of patients have serum antibodies to HIV-1 p24 (compared with $<1 \%$ in normal subjects $)^{25}$ and do not have antibodies to HTLV-I; the latter result was also confirmed in a study using sera from 36 SLE patients. ${ }^{26}$ In our study, Western blotting revealed weak reactivity against a number of retroviral antigens: p21, p19, p24, p38 and gp46 (reactivity against p42 tax was noted in the majority of samples, including normal: this observation was consistent with the kit specification protocol). These results may be explained either by the presence of a retrovirus or by molecular mimicry. ${ }^{27}$ The latter may occur when an organism shares sequence or amino acid homology with a normal cellular component, for example HIV gp41 and HLA class II. ${ }^{28}$ While it has been suggested that polyclonal B cell activation may account for the presence of cross reactive antibodies, it is apparent that pokeweed mitogen stimulation of HIV seronegative patients has produced only antibodies reactive with envelope glycoproteins gp120, gp120 and p66. ${ }^{29}$ An alternative explanation is the presence of rheumatoid factor, which is a common problem causing false positivity in assay systems. However in our study, there was no correlation between the presence of rheumatoid factor and ELISA reactivity. Furthermore, not all rheumatoid factor positive sera exhibited reactivity in Western blotting.

Previous molecular biology investigations have focused on nucleotide sequence analysis of SLE plasma DNA which revealed $80 \%$ sequence homology with the gag-pol overlap region of HIV-1. ${ }^{30}$ Furthermore an exocrinopathy resembling pSS has been described in mice transgenic for the HTLV-I tax (transactivating) gene. ${ }^{31}$ In order to assess if a known exogenous retrovirus was involved we pursued a direct approach using PCR for HTLV and HIV on our cohort of patients. Intact DNA (validated using $\beta$-globin primers) from peripheral blood mononuclear cells was amplified using primers for HTLV-I tax and HIV-1 gag regions. However, examination of patients with cross reactive antibodies to retroviral products proved negative. Evidently either integrated provirus was not present or the failure to incriminate a retroviral agent 
might have been caused by the paucity of retroviral infected peripheral blood lymphocytes (in $\mathrm{HIV}$, for example, $<1 \%$ of peripheral $\mathrm{T}$ cells are infected ${ }^{32}$ ). Because a putative causative retrovirus might be present in greater quantity at the site of inflammation, we also obtained synovial tissue and muscle biopsies. HTLV-I and HIV-1 were not amplified from these sites of inflammation and hence these retroviruses are unlikely to be involved in causing these rheumatological diseases. The primers used were highly specific for HTLV and HIV and therefore there remains a possibility that, should other lentiviruses be involved, the primers would have been inappropriate. Amplification using other consensus or degenerate primers may provide an alternative approach. Whilst we were unable to test salivary gland tissue, it has recently been reported that sequences homologous to HTLV-I tax gene are detectable in the labial salivary glands of a subset of patients wtih Sjögren's syndrome. ${ }^{33}$ Interestingly, there is no evidence of other HTLV-I gene products. Deletion of large segments of the provirus whilst leaving tax intact and functional is characteristic of HTLV-I induced tumours. ${ }^{34}$ We have also noted such deletion phenomenon in $T$ cell clones derived from HTLV-I infected individuals (J Richardson and A M L Lever, personal observations). Thus a deleted exogenous virus or an endogenous retrovirus with strong sequence homology to HTLV-I may be implicated in the Japanese study. ${ }^{33}$

Within the human genome, endogenous

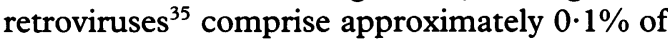
the human genome and are divided into 16 distinct families with copy numbers ranging from 1 to 10000 per haploid genome. ${ }^{36}$ They are inherited in a mendelian manner and their role in autoimmune disease is of interest since, in the murine SLE model, animals express an endogenous $8.4 \mathrm{~kb}$ retroviral transcript. ${ }^{37}$ Endogenous retrovirus are presumed to originate from infectious retroviruses and are generally stable genetic elements but may transpose, resulting in new integrations within or near a gene, thereby altering its expression. This property of cell activation induced expression is shared by a number of murine endogenous retroviruse ${ }^{2}$ and may be relevant to the induction or perpetuation of autoimmunity. Furthermore, the expression or recognition of endogenous retroviral sequences might explain both the familial aggregation of autoimmune diseases and detection of cross reactive antiretroviral antibodies. A transcriptionally active novel human endogenous retrovirus, HRES-1, has been isolated ${ }^{38}$ and is the first human endogenous retroviral sequence found to be capable of protein expression. Polyclonal antibodies raised against peptides of HRES-1 (with homology to the gag protein of HTLV-I) recognise a $28 \mathrm{kDa}$ protein, localised to the cytoplasm and nuclear bodies in $\mathrm{H} 9$ human $\mathrm{T}$ cells. ${ }^{39}$ In addition, sera of patients with progressive systemic sclerosis $(23 \%)$, SLE $(21 \%)$, and primary SS $(10 \%)$ appear to contain significantly greater HRES-1 peptide binding activity than sera of normal donors, suggesting that HRES-1 $28 \mathrm{kDa}$ protein may serve as an autoantigen eliciting autoantibodies cross reactive with HTLV antigens. However, a subsequent study ${ }^{40}$ demonstrated the presence of HRES-1 protein in salivary gland biopsies of patients and normal subjects, thereby questioning the role of this particular endogenous retrovirus.

This study serves to highlight the difficulty in incriminating retroviral agents in rheumatological diseases and the discrepant data which may be derived from serological and molecular biological approaches. Recent data ${ }^{41}$ indicate that HTLV-I antibody testing is concordant with the results obtained by PCR if unequivocal positive results are observed in Western blotting. Our data convincingly exclude the role of exogenous retrovirus HTLV-I and HIV-1 in the aetiology of rheumatological diseases.

This work was supported by the Arthritis and Rheumatism Council.

1 Carson D A. Genetic factors in the etiology and pathogenesis of autoimmunity. FASEB f 1992; 6: 2800-5.

2 Krieg A M, Steinberg A D. Retroviruses and autoimmunity. F Autoimmun 1990; 3: 137-66.

3 Sato K, Maruyama I, Maruyama Y, et al. Arthritis in patients infected with human $T$ lymphotropic virus type I. Arthritis Rheum 1991; 34: 714-21.

4 Calabrese L M. Autoimmune manifestations of human immunodeficiency virus (HIV) infections. Clin Lab Med 1988; 8: 269-79.

5 Nishioka K, Maruyama I, Sato K, Kitajima I, Nakajima Y, Osame $M$. Chronic inflammatory arthropathy associated with HTLV-I. Lancet 1989; i: 441.

6 Narayan O, Sheffer D, Clements J E, Tennekoon G. Restricted replication of lentiviruses. $\mathscr{f}$ Exp Med 1985; 162: 1954-69.

7 Talal N, Dauphinee M J, Dang H, Alexander S, Garry R. Evidence suggesting a retroviral etiology for human autoimmune disease. In: Progress in Immunology VII. 7th International Congress of Immunology. Berlin: SpringerVerlag, 1989: 837-41.

8 Eguchi K, Matsuoka N, Ida H, et al. Primary Sjögren's syndrome with antibodies to HTLV-I: clinical and laboratory features. Ann Rheum Dis 1992; 51: 769-76.

9 Ziegler B, Gay R E, Huang G, Fassbender H, Gay S. Immunohistochemical localization of HTLV-I p19- and p24-related antigens in synovial joints of patients with rheumatoid arthritis. Am $\mathcal{f}$ Pathol 1989; 135: 1-5.

10 Garry R F, Fermin C D, Hart D J, Alexander S S, Donehower L A, Luo-Zhang $H$. Detection of a human intracisternal A-type retroviral particle antigenically intracisternal A-type retroviral particle
related to HIV. Science 1990; 250: 1127-9.

11 Pelton B K, North M, Palmer R G, et al. A search for retrovirus infection in systemic lupus erythematosus and
rheumatoid arthritis. Ann Rheum Dis $1988 ; 47: 206-9$.

12 Panayi G S, Dalgleish A G. Retroviruses in rheumatoid arthritis. Ann Rheum Dis 1986; 45: 439.

13 Saiki R K, Gelfand D H, Stoffel S, et al. Primer-directed enzymatic amplification of DNA with a thermostable DNA polymerase. Science 1988; 239: 487-91.

14 Arnett F C, Edworthy S M, Bloch D A, et al. The American Rheumatism Association 1987 revised criteria for the classification of rheumatoid arthritis. Arthritis Rheum 1988; 31: 314-5

15 Bohan A, Peter J B, Bowman R L, Pearson C M. A computer assisted analysis of 153 patients with polymyositis and dermatomyositis. Medicine 1977; 56: myositis

16 Skopouli F N, Drosos A A, Papaioannou T, Moutsopoulosos H M. Preliminary criteria for Sjögren's syndrome. Scand $\mathcal{F}$ Rheumatol Suppl 1986; 61: 22-5.

17 Tan E M, Cohen A S, Fries J F, et al. The 1982 revised criteria for the classification of systemic lupus erythematosus. Arthritis Rheum 1982; 25: 1271-7.

18 Kwok S, Kellogg D, Ehrlich G, Poiesz B, Bhagavati S Sninsky J J. Characterization of a sequence of human T cell leukemia virus type I from a patient with a chronic progressive myelopathy. $\mathcal{F}$ Infect Dis 1988; 158: 1193-7.

19 Rayfield M, De Cock K, Heyward W, et al. Mixed huma immunodeficiency virus (HIV) infection in an individual demonstration of both HIV type 1 and type 2 proviral sequences by using polymerase chain reaction $f$ Infect $D$ is 1988; 158: 1170-5.

20 Nishikai $M$, Sato A. Human T lymphotropic virus type I and polymyositis and dermatomysitis in Japan. Arthritis Rheum 1991; 36: 791-2.

21 Lolli F, Ernerudh J, Kam-Hansen S, Link H. No association between antibodies to HTLV-I and polymyositis, between antibodies to HTLV-I and polymyositis,
rheumatoid arthritis and SLE. Scand 7 Rheumatol 1987; 16: 213-5. 
22 Mora C A, Garruto R M, Brown P, et al. Seroprevalence of antibodies to HTLV-I in patients with chronic neurological disorders other than tropical spastic paraparesis. Ann Neurol 1988; (suppl) 23: 192-5.

23 Irving W, White $P$, Cambridge G. Antibodies to HTLV-I in sera from patients with connective tissue diseases. Ann in sera from patients with

24 Talal N, Dauphinée M J, Dang H, Alexander S S, Hart D J, Garry R F. Detection of serum antibodies to retroviral proteins in patients with primary Siögren's syndrome (autoimmune exocrinopathy). Arthritis Rheum 1990; 33: 774-81

25 Talal N, Garry R F, Schur P H, et al. A conserved idiotype and antibodies to retroviral proteins in systemic lupus erythematosus. $\mathcal{F}$ Clin Invest 1990; 85: 1866-78.

26 Boumpas D T, Popovic M, Mann D L, Balow J E, Tsokos G C. Type $C$ retroviruses of the human $T$ cell leukemia family are not evident in patients with systemic lupus erythematosus. Arthritis Rheum 1986; 29: 185-8.

27 Barnett L A, Fuijnami R S. Molecular mimicry: mechanism for autoimmune injury. FASEB $\mathcal{f} 1992$; 6: mechan

28 Golding H, Shearer G M, Hillman K, et al. Common epitope in human immunodeficiency virus (HIV)-1-gp41 and HLA class II elicits immunosuppressive autoantibodies capable of contributing to immune dysfunction in HIV-1 infected individuals. F Clin Invest 1989; 83: $1430-5$.

29 Dang H, Dauphinée $M$ J, Talal N, et al. Serum antibody to retroviral gag proteins in systemic sclerosis. Arthritis Rheum 1991; 34: 1336-7.

30 Kalden J R, Winkler T, Krapf F. Are retroviruses involved in the aetiology of rheumatic diseases? $\mathrm{Br} \mathcal{F}$ Rheumatol 1991; (suppl) 30: 63-9.

31 Green J E, Hinrichs S H, Vogel J, Jay G. Exocrinopathy resembling Siögren's syndrome in HTLV-I tax transgenic mice. Nature 1989; 341: 72-4.
32 Schnittman S M, Psallidopoulos M C, Lane H C, et al. The reservoir for HIV-1 in human peripheral blood is a T cell that maintains expression of CD4. Science 1989; 245: 305-8.

33 Sumida $\mathrm{T}$, Yonaha $\mathrm{F}$, Maeda $\mathrm{T}$, et al Expression of sequences homologous to HTLV-I tax gene in the labial salivary glands of Japanese patients with Sjögren's salivary glands of Japanese patients with
syndrome. Arthritis Rheum 1994; 37: 545-50

34 Korber B, Okayama A, Donnelly R, Tachibana N, Essex M. Polymerase chain reaction analysis of defective human T-cell leukemia virus type 1 proviral genomes in leukemic cells of patients with adult T-cell leukemia. $\mathcal{F}$ Virol 1991; 65: 5471-6.

35 Stoye J, Coffin J. Endogenous retroviruses. In: Weiss R, Teich N, Varmus H, Coffin J, eds. RNA tumor viruses, Vol. 2. New York: Cold Spring Harbor Laboratory, 1985: 357-404.

36 Larsson E, Kato N, Cohen M. Human endogenous proviruses. Curr Topics Microbiol Immunol 1989; 148: proviruses.

37 Krieg A M, Steinberg A D, Khan A S. Increased expression of novel full-length endogenous MCF-related transcript of novel full-length endogenous MCF-related transcript

38 Perl A, Roseblatt J D, Chen I S Y, et al. Detection of cloning of a new HTLV-related sequences in man. Nucl Acid Res of a new HTLV-rel

39 Banki K, Maceda J S, Hurley E, et al. HRES-1, a human endogenous retroviral sequence encodes a 28 kd protein: a possible autoantigen for HTLV gag-reactive autoantibodies. Proc Natl Acad Sci USA 1992; 89: 1939-43.

40 Brookes S M, Pandolfino Y A, Mitchell T J, et al. The immune response to and expression of cross-reactive retroviral gag sequences in autoimmune disease. $\mathrm{Br} F$ Rheumatol 1992; 31: 735-42.

41 Busch M P, Murphy E, Nemo G. More on HTLV tax and mycosis fungoides. N Engl f Med 1993; 329: 2035. 